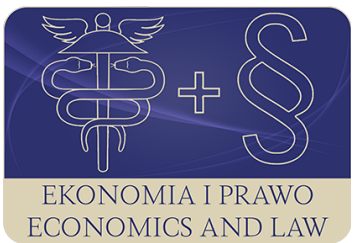

EKONOMIA I PRAWO. ECONOMICS AND LAW

Volume 19, Issue 4, December 2020

p-ISSN 1898-2255, e-ISSN 2392-1625

www.economicsandlaw.pl

ORIGINAL ARTICLE

received 04.02.2020; revised 02.05.2020; accepted 31.12.2020

Citation: Witkowski, J. (2020). Legal forms of nature protection in local spatial planning: selected problems on the example of communes in Poland. Ekonomia i Prawo. Economics and Law, 19(4): 801-816. doi:10.12775/EiP.2020.052.

\title{
Legal forms of nature protection in local spatial planning: selected problems on the example of communes in Poland
}

\section{JACEK WITKOWSKI}

Lublin University of Technology, Faculty of Management, Department of Economics and Economic Management, ul. Nadbystrzycka 38D, 20-618 Lublin, Poland

曰j.witkowski@pollub.pl

(D) orcid.org/0000-0001-6047-2868

\begin{abstract}
Motivation: Proper spatial planning is very important in the context of taking into account the needs related to environmental protection in local development. The local self-governments should play an important part in this case because they are responsible for preparation of spatial development plans determining the scale and directions of developed forms of activities and, consequently, having significant influence on the effective protection of valuable natural ecosystems.

Aim: The purpose of the article is to characterize the activity of local governments in the field of spatial planning in terms of considering restrictions on areas and facilities covered by legal forms of nature protection. The analysis encompassed $49 \mathrm{com}-$ munes in the territory of Lubelskie Voivodship situated in south-eastern part of Poland and the results constituting the basis for conclusions were obtained by means of diagnostic poll method and by means of analysis of selected statistical data. The questionnaire questions were addressed to the mayors of communes.

Results: Some part of legally protected areas is situated out of the range of impact of local plans of spatial development constituting the acts of local law. Some studies of land use conditions and directions used by communes as the basis for preparation of local plans were prepared a long time ago for conditions determined in already invalid regulations. Additionally, in many entities under studies, the natural stocktaking, the results of which should be considered in such studies, was carried out many years ago or never. In communes with Natura 2000 sites, this new protection form did not contribute generally to increased engagement of officials in the scope of local development plans modification.
\end{abstract}


The above results may lead to the conclusion that spatial planning at the local level is associated with some threats to the protection of local natural resources in the future.

Keywords: spatial planning; nature protection; commune

JEL: R58; Q56; Q01; Q20

\section{Introduction}

The plans of spatial development constitute important tools in the scope of local development management. The lowest level of self-government authorities in various countries is usually equipped with competences for their preparation, adoption and implementation. Owing to the fact that such documents contain the provisions concerning the methods of use of various areas, also those excluded from normal use due to presence of valuable natural ecosystems, they should be also seen as the key items in terms of nature protection. In theory, the above studies should consider all the areas encompassed by legal protection forms as well as should take into account any restrictions resulting therefrom. In practice, we often have to deal with certain abnormalities or omissions which, in future, may result in insufficient implementation of protective functions.

The purpose of this work is to characterize the activity of local governments in the field of spatial planning in terms of considering restrictions on areas and facilities covered by legal forms of nature protection. In particular, an attempt was made to answer the following questions:

- are the local spatial planning documents current and do they correctly include legally protected areas and facilities?

- whether all legal forms of nature protection are covered by development plans with legal force?

- what are the prospects for the proper course of the process of potential modification of spatial development plans so that they respect the tasks in the field of nature protection?

The survey covered selected municipalities located in the Lubelskie Voivodeship in the south-eastern part of Poland.

\section{Literature review}

The question of spatial planning complying with applicable requirements in the scope of nature protection becomes a key part of sustainable development concept which was born about thirty years ago and is currently applied in practice around the world by various public and private institutions. Obviously, numerous studies emphasize the essence of this concept and, consequently, the need to balance the social, economic and ecological aims with simultaneous indication of self-government authorities as entities entrusted with special obligations in this respect (Harris, 2000; Kates et al., 2005; OECD, 2002). Simultaneously, however, it has been noted that the role of self-governments in the process consisting in preparation and implementation of environment 
protection solutions is diversified in various legislative systems. In some countries, local government competences are severely limited to the benefit of central government, in others local authorities have relatively broad powers and can develop and implement stricter rules (Mazur, 2011, pp. 11-12).

With regard to local development plans and adherence to the provisions concerning the state of natural environment which are included therein, this issue has been discussed by numerous authors on the basis of recently implemented European protection programme Natura 2000. For instance, in the report prepared in the year 2017 for European Commission, attention has been drawn to the need of spatial planning in a manner ensuring the communication between individual protected areas and their surroundings. Mention is also made of two types of unfavourable spatial impact on protected areas, namely land abandonment on the one hand and excessively intensified use thereof on the other hand. In the conclusions it is proposed to apply two types of strategies in spatial development i.e. integration or subdivision of conflicting social and economic functions of Natura 2000 sites depending on their specific features (Simeonova et al., 2017, pp. 51-53). Other authors inform about the problems associated with the implementation of the European Ecological Network and indicate to irregularities occurring in this context and resulting from the source anchored also in the local development plans. For instance, Beunen (2006, p. 2, 16) described the implementation of Habitats and birds directive in Holland stating among others that this process caused, except of other problems, delay of planning processes themselves. Beunen $(2006$, p. 2, 16) also emphasizes the fact that, in many cases, previously made decisions on investment were overruled by local courts deciding that the consideration of recommendations included in the Habitats directive was insufficient. In the opinion of Proebstl (2003, p. $345)$, the engagement of local interest groups can protect against similar conflicts and, simultaneously, can warrant effectiveness of nature protection. The issue of participation of local entities in creation and implementation of sustainable development plans, which is obviously closely associated with development issue, has been also raised in a study relating to Lithuanian conditions. In this case, the authors emphasize that self-government authorities are particularly responsible for successful implementation of the process because they should support and stimulate the enthusiasm of participating social factors in course of strategy creation and should monitor the progress in this scope (Ciegis \& Gineitiene, 2008, p. 111). Sometimes, the process of decentralization in the scope of planning and environment management goes even further. In a publication describing the situation in Scandinavian countries, we can read, among other things, that the role of Swedish self-governments with traditionally broad spatial planning competences has been marginalised in favour of newly created local structures. In these structures representatives of private organizations are operating alongside local officials. The competences of these councils include, for example, the management of nature reserves and supplying information to land owners and users. They are also entitled to make decisions on tax exemp- 
tions. The authors conclude that such model of management assuming separate solutions designed for specified protected areas leads to increased consensus on the implementation of protection aims and, therefore, it is probably better adapted to the existing socio-ecological context (Hongslo et al., 2016, p. 7, 13). An interesting aspect associated with spatial planning in the context of nature protection management has been presented by Hoffman (2017, p. 562). On the basis of case study, this author concluded that private owners would be more likely to initiate environmental activities under multilateral agreements with other persons. The challenge in the process of spatial planning, if it is to lead to the protection of natural resources on private land, is therefore to ensure cooperation between the owners when negotiating commitment to a shared vision of the future. The planners should take care to ensure participatory aspects of the planning in order to carry out the process of plans creation in the form of public discussion forum.

The local self-government authorities in Poland, responsible for management of administrative units called communes, prepare and implement two types of planning documents: the study of land use conditions and directions determining long term development aims and the executive summary plan in the form of local spatial development plan. Woźniak (2011, pp. 140-141) emphasizes that, particularly at commune level, ensuring the social participation is a helpful tool in seeking a compromise between the interests of entities participating in the planning and development process. She indicates three levels of potential conflicts when planning sustainable development, namely conflicts between: individual interest - individual interest, individual interest — public interest, as well as conflict in the event that the state (regional) interest does not coincide with the interest of the municipality. In other article published by the same author, it is denoted that the local plans in Polish conditions suffer from their adoption for ever smaller areas and from the planning without proper diagnosis of natural conditions of the commune (Woźniak, 2015, p. 41). Further study refers to relation between the development plans and the implementation of the aims of nature protection which are discussed on the example of specified commune (Stęszew — western Poland). Although the authors state that there is no evident impact in this case, they express the opinion that certain provisions included in the plans contribute to limitation of development of local Natura 2000 sites and, simultaneously, the other provisions bring certain dangers associated with excessive increase of built up areas within protected sites (Gatecka-Drozda et al., 2019, p. 594). For the areas of European Ecological Network constituting almost $20 \%$ of total surface area of Poland, protection tasks to be determined should be also considered in development plans. Mastalska-Cetera \& Krajewski (2015, pp. 152-153), based on the analysis of local planning documents in the municipalities of the Bolesławiec poviat (south-western part of Poland), state that there is a good basis for proper management of the European Ecological Network in the absence of restrictions on the development of municipalities. Additionally, the authors mention that, in terms of already 
prepared designs of protection tasks, any supplementations of local planning documents were unnecessary, with one exception. However, the conclusions expressed by Antolak (2011, p. 105) on similar subject are less optimistic. As a result of the analysis of several cases originating from various parts of Poland and concerning commune plans of spatial development, the author concluded that the lack of ecological and aesthetic awareness of decision makers (including officials in communes responsible for spatial planning and environment protection) results in uncontrolled changes in natural environment in Poland. He notes, by the way, that the recommendations of external consultative bodies are often duplicates of the same best practices.

\section{Regulations regarding nature conservation in local spatial development plans in Poland: legal basis}

From the content of several Polish legislative acts it appears that the self-governments managing the communes should prepare and implement the plans of spatial development in a manner considering the needs in the scope of nature protection.

At the beginning, we should mention the Act on communal self-government (1990, art. 7) determining own tasks of commune authorities encompassing, among other things (specified in the first place), issues associated with spatial order, environment and nature protection as well as water management. The same document determines, except of other activities, adoption of the study of land use conditions and directions for commune (hereinafter called the study) as well as local plans of spatial development of commune as the exclusive jurisdiction of commune council i.e. one of other bodies of commune self-government authorities (Act on communal self-government, 1990, art. 18). The issues associated with local development are determined in more detailed manner in the separate act on spatial planning and development. From the above act it appears that the study should consider the provisions included in other planning documents, namely in documents at supralocal level (e.g. the concept of spatial development for Poland, development strategies and development plans for individual voivodships) as well as the documents for individual communes (particularly development strategy). The above act also determines, except of conditions to be considered in the study, those resulting from the state of spatial order and from the requirements in the scope of its protection as well as those resulting from the presence of objects and areas protected under separate acts (Act on spatial planning and development, 2003, art. 9, 10). Further part of the above legal act determines the aims and principles concerning the preparation of the local plans of spatial development which, unlike the study, are the acts of local law. The purpose of these plans is to determine the use of lands and the methods of their development whereby the legislator clearly provides that, on this occasion, it is mandatory to determine the principles of environment, nature and landscape protection (Act on spatial planning and development, 2003, art. 14-15). 
Further regulations which are important from the point of view of the subject being discussed are included in the Nature conservation act (2004). Pursuant to the act, commune executive body i.e. head of commune, mayor or president (depending on the type of commune) belongs to nature protection bodies (Nature conservation act, 2004, art. 91). Additionally, commune councils are provided with competencies authorizing them to create certain forms of legal nature protection (Nature conservation act, 2004, art. 44). Therefore, to make such decisions it is obviously required to introduce proper modifications into local development studies. On the other hand, in the case of area forms of nature protection managed by entities independent of local authorities (national park, nature reserve, landscape park, protected landscape area, Natura 2000 area), the act requires that draft development plans be consulted by local governments with these entities (Nature conservation act, 2004, art. 10, 13, 16, 23, 30). The problem of changes in development plans in terms of requirements determined in protection plans and protection tasks plans for Natura 2000 areas seems to be particularly important in this case (Nature conservation act, 2004, art. 28, 29).

In case of the both types of documents prepared at commune level and associated with the development (the study and local plan) it is required to carry out so called strategic assessment of environmental impact which directly results from the Act on providing information on the environment and its protection, public participation in environmental protection and on environ-mental impact assessments (2008, art. 46).

However, there are significant doubts about applicable Polish legal solutions in the scope of spatial planning at commune level. For instance, according to the opinion expressed in a report submitted by the Supreme Chamber of Control (NIK), because the study of land use conditions and directions of spatial development at commune level is not an act of local law, this study does not constitute the legal basis for issuing of administrative decisions on land building up and development conditions. This situation may lead, in the areas not encompassed by local development plans, to the implementation of investment nonconforming with the assumptions of local policy and spatial structure of the commune (NIK, 2016, p. 9). This problem can also affect the compliance with the requirements associated with the protection of local natural values.

\section{Materials and methods}

The following methods were used in the study, the results of which will be presented below:

- diagnostic survey based on a questionnaire;

- statistical data analysis.

In the period from January to April 2019 a survey was conducted among the mayors of 49 communes (i.e. the smallest territorial administrative units in Poland) located in the Lubelskie Voivodeship in the south-eastern part of Poland. The persons managing the work of local governments responded to 34 
closed questions contained in the survey form by ticking one or several options in each of the points. The questions concerned issues related to broadly understood environmental management and included, among others, matters such as: possession of strategic documents by the commune and their content, the number of people with natural education working in commune offices, investments undertaken in the commune, direct actions for nature protection and those related to the implementation of the Natura 2000 program (applies to some municipalities).

The communes covered by the survey were selected in such a way that area and object forms of nature protection were located in each of them. Areas of the European ecological network Natura 2000 have been marked out in 29 municipalities. Information on the occurrence of forms of protection in communes was taken from the database of the General Directorate for Environmental Protection (2020).

To determine the scale of coverage of legal forms of protection (especially protected areas) with local development plans, an analysis of data of the Central Statistical Office was carried out. This institution is a government administration office in Poland and collects and shares statistical information on most areas of public life. Materials regarding the percentage of area of surveyed municipalities covered by local plans were retrieved from GUS (2019).

\section{Research results}

\subsection{Legally protected areas and local spatial development plans}

As already has been said, communes constituting the research area are characterized by the presence of valuable natural areas. A part of these areas is covered by legal protection forms. The areas of European ecological network Natura 2000 are situated inside the boundaries of 29 administrative units. Furthermore, different forms of protection determined in the Nature conservation act (2004) have been established in majority of them i.e. nature monuments, ecological sites, protected landscape areas, landscape parks and, less commonly, nature reserves and national parks (GDOŚ, 2019). Obviously, the percentage of these forms in surface area of individual communes is diversified (table 1).

When it comes to the local plans of spatial development, the degree of coverage of surface area of individual communes with them provides proof of significant improvement in comparison with situation from a few years ago. At that time, the lack of local plans and, additionally, even the reduction of surface areas encompassed by them was recorded at generally low coverage ratio (Prus, 2012, p. 132). In relation to research sample, in 21 communes their whole surface area is covered by above plans and this coverage is almost equal to $100 \%$ in the next ten communes. However, on the other hand, the local development plan in ten units covers less than $1 \%$ of surface area (table 2). 
Combining the indicators illustrating the percentage of nature protection forms with surface areas encompassed by local development plans in the whole surface area of individual communes we can found that land use has been determined in a proper and, as emphasized previously, legally binding manner only for a part of areas encompassed by legal protection. In case of a third of self-government units (16 communes), the percentage of coverage by local plans is lower in comparison with the indicator determining the scale of occurrence of area - oriented forms of nature protection including Natura 2000 sites. When it comes to national and landscape parks, protected landscape areas, nature and landscape complexes, this opinion relates to 14 communes. Although, additionally, the same situation takes place in two communes in relation to European Ecological Network areas. In some cases, the disproportions are really significant and the difference between percentages is even close to $90 \%$. A little bit surprising is the fact that this situation, unfavourable in terms of performance of protection tasks, also relates to communes which are commonly known in the whole region due to the presence of numerous valuable natural values.

The location beyond boundaries of legally binding development plans is less problematic in case of nature monuments. Although, also in this case there are individual communes with the number of such type objects per 100 square kilometers significantly exceeding the average value for the whole region. However, they are not currently protected through clearly determined principles of use of their location areas (there are five communes like this and they constitute 10\% of their total number encompassed by analysis).

\subsection{The study of land use conditions and directions of spatial development}

The study of land use conditions and directions of spatial development is an obligatory document for communes in Poland. Already the previous Act on spatial development (1994) imposed on them an obligation to prepare the study under the pain of loss of binding force of previously applicable local development plans. Nevertheless, the research carried out by Witkowski (2008), i.e. after the entry into force of the new currently binding act, demonstrated that this task was not completed by the majority of commune authorities in Lubelskie Voivodship within prescribed time limit. In February of the above mentioned year there were still communes where their executive body (head of commune, mayor or president of town) has not prepared relevant study (Witkowski, 2008, p. 121). Thus, one can speak of a certain inertia of local authorities in accepting the study, which was found 10 years ago. Other studies also indicate limited tendency of officials to modify the content of development plans and frequent use previously prepared documents as the basis (e.g. MBPR, 2015). In these circumstances, one may have doubts about the quality of these studies from the point of view of proper environmental management 
From answers obtained in questionnaires it appears that the highest percentage of communes encompassed by the research achieves the objectives and performs their tasks on the basis of relatively new documents prepared during the period of recent 5 years (22 indications - $45 \%$ of total number). Nevertheless, significant number of respondents (15 persons - 30\%) stated that the study adopted more than 15 years ago is used in their communes as the basis for spatial planning (table 3). It was the time when the outlining of Natura 2000 areas was commenced and when the provisions of the previous Nature conservation act (1991) were binding.

A standard procedure in this case consists in the commission of the study preparation to specialized external entities but the employees of commune offices should verify obtained designs. However, in almost half of communes encompassed by the research (23 among 49 units) there are no appointed organizational units dealing with issues directly associated with environment protection in local offices. Simultaneously, proper education of the staff of officials in this scope is also problematic because, most frequently, only one person with proper qualifications is employed (55\% of all answers). Despite this, the study shows that only every third mayor sees the need for qualifications raising in the scope of biodiversity protection (16 persons) and every eight respondent - in the scope of natural compensation - extremely important in the impact assessment (6 persons).

For spatial planning complying with applicable requirements in the scope of nature protection it is necessary to properly identify the distribution and condition of local natural resources through the execution of natural stocktaking. Such stocktaking makes it possible to gain the knowledge about environment in local scale and encompasses the diagnosis of existing situation as well as the characteristics of its resistance to anthropopressure and evaluation of environment transformations status (Koreleski, 2009, pp. 38-39). Although more and more self-governments are interested in such type of undertaking, still relatively many self-governments have not commenced any activities in this scope. Another problem is related to the reliability of these documents and readiness to update them. From answers given in questionnaire it appears that in about one fourth of communes encompassed by research (13 indications) any natural stocktaking was never carried out and in the group of other units, the majority of such stocktaking took place more than ten years ago (table 4). Remote time of the execution of natural stocktaking is important in this case not only in terms of highly probable changes which could occur in natural environment during such long period of time but also in terms of a manner of the execution of natural stocktaking itself. It should be mentioned that, in the year 2015, new guidelines have been introduced in the scope of methodology of execution of such type of reconnaissance (Act amending the act on providing information on the environment and its protection, public participation in environmental protection and on environmental impact assessments and certain other acts, 2015) which, for obvious reasons, could not be considered by $55 \%$ self-governments encom- 
passed by the analysis (i.e. all those self-governments which carried out natural stocktaking 5 years ago or earlier).

Combining the above answers with the data discussed earlier, it turns out that in almost every fourth of the surveyed communes (1l units) legally binding development methods were established only for some of the areas covered by protection measures, and local governments are based on the study of conditions and directions of spatial development adopted at least 10 years ago. Additionally, among this group in nine cases, there is also a lack of inventoried nature resources or an inventory carried out a decade ago or earlier.

Pursuant to the Nature conservation act (2004), the study of land use conditions and directions of spatial development (as well as other local development plans) should consider plans for protective tasks for Natura 2000 areas. It should be assumed that, in many cases, this is or will be equal to modifications of provisions included in the studies. Mentioned plans are often still in creation phase but the process of their creation should be monitored by communes managing entities. Responding heads of 29 communes where the areas protected under European programme are located were also given the opportunity to express their attitude towards the results of consultations associated with protection plans and, furthermore, to indicate already initiated activities during the period of recent years in connection with the new form of protection. Less than half of them (ll persons) declared their satisfaction with the progress of consultation (positive attitude). However, more respondents (14 persons) did not express their opinion on this subject which may result, although not necessarily, from insufficient knowledge of the process progress itself and the content of projects. More explicit conclusion results from the distribution of answers to the question about the actions resulting from the functioning of protected areas and from the necessity to prepare for decision making in the conditions of implemented protection plans. Faced with a choice between several options, most frequently the respondents admitted the lack of actions ( 14 commune heads) and the modification of existing development plans has been indicated as the reaction by every fifth of them (7). It should also be added that, as results from the research, until now, the majority of commune authorities does not have complete register of the owners of Natura 2000 areas situated in commune territory. This definitely will not constitute a factor facilitating the introduction of revisions into studies or local plans when considering the necessity of cooperation between self-governments and private owners recommended by some authors in this context.

Summing up the results of the study, it should be stated that local self-governments in the analyzed communes should provide more favorable conditions for the implementation of the statutory protective functions of local natural values. The way to do this is certainly the raising of appropriate qualifications by the clerical staff, greater involvement in adopting local development plans so that all forms of protection are covered by them, as well as regular carrying out of nature inventory. Local officials should also be more active and ready to take 
action to correct previously implemented development plans (as required by law).

\section{Conclusions}

In course of preparation of spatial development plans, self-government authorities at the lowest level should consider therein the limitations in use of some lands resulting from protective functions of such lands. Experience gained by more than one European country indicate that various problems can arise in the phase of such plans creation as well as in further implementation of the provisions included therein. These difficulties may be the result of insufficient preparation of clerical staff to carry out new planning tasks, certain neglects or the prioritization of economic interest over ecological.

The presented results of the study carried out in the communes of the Lubelskie Voivodeship indicate that some local governments did not ensure that the presence of local natural assets subject to legal protection and their restrictions in use were fully taken into account in the most important planning documents. Many protected areas are not covered by local development plans with legal force, additionally some of the documents constituting the basis for the creation of these plans (studies of conditions and directions of spatial development) were adopted before significant changes in the Polish nature protection system were introduced. In connection with established lack of natural stocktaking in significant part of communes or with execution of such reconnaissance long time ago, this situation can result in problematic up-to-date status and quality of at least a part of these basic planning documents.

The aforementioned problems give rise to concerns that clerical decisions regarding projects implemented within protected areas may often be taken in a discretionary manner and without sufficient consideration of protective requirements.

On the basis of the study, it was found that local governments were little involved in changing the development plans due to the emergence of a new form of nature protection in the form of Natura 2000 sites. Some of the entities managing municipalities also do not seem to attach much importance to the issue of consultations on the plans for protecting the areas of the European ecological network. If the officials' approach in this matter does not change, supplementing spatial plans with new provisions or modifying those existing in terms of new requirements in the field of nature protection may prove difficult in the future.

\section{References}

Antolak, M. (2011). Praktyka ochrony środowiska w sporządzaniu gminnych dokumentów planistycznych: na wybranych przykładach. Problemy Ekologii Krajobrazu, 31. 
Beunen, R. (2006) European nature conservation legislation \& spatial planning: for better or for worse. Journal of Environmental Planning and Management, 49(4). doi:10.1080/09640560600747547.

Ciegis, R., \& Gineitiene, D. (2008). Participatory aspects of strategic sustainable development planning in local communities: experience of Lithuania. Technological and Economic Development of Economy, 14(2). doi:10.3846/1392-8619.2008.14.107-117.

Gałecka-Drozda, A., Raszeja, E., Szczepańska, M., \& Wilkaniec, A. (2019). Land cover changes in Natura 2000 areas located in suburban zones: planning problems in the context of environmental protection. Polish Journal of Environmental Studies, 28(2). doi:10.15244/pjoes/80894.

GDOŚ. (2019). Centralny rejestr form ochrony przyrody. Retrieved 18.03.2020 from https://crfop.gdos.gov.pl.

General Directorate for Environmental Protection. (2019). Retrieved 18.03.2020 from http://crfop.gdos.gov.pl.

GUS. (2019). Bank danych lokalnych. Retrieved 18.03.2020 from https://bdl. stat.gov.pl.

Harris, J.M. (2000). Basic principles of sustainable development. Global Development and Environment Institute Working Paper, 00-04.

Hoffman, M. (2017). The role of public land use planning in facilitating conservation on private land. Natural Areas Journal, 37(4). doi:10.3375/043.037.0412.

Hongslo, E., Hovik, S., Zachrisson, A. \& Lundberg, A.K.A. (2016). Decentralization of conservation management in Norway and Sweden: different translations of an international trend. Society \& Natural Resources, 29(8). doi $: 10.1080 / 08941920.2015 .1086456$.

Kates, R.W., Parris, T.M., \& Leiserovitz, A.A. (2005). What is sustainable development: goals, indicators, values, and practice. Environment: Science and Policy for Sustainable Development, 47(3). doi:10.1080/00139157.2005.1 0524444.

Koreleski, K. (2009). Problematyka ochrony i kształtowania środowiska w dokumentach służących realizacji zrównoważonego rozwoju gmin. Infrastruktura i Ekologia Terenów Wiejskich, 4.

Mastalska-Cetera, B., \& Krajewski, P. (2015). Obszary Natura 2000 jako uwarunkowanie planowania rozwoju regionalnego. Studia KPZK, 161.

Mazur, E. (2011). Environmental enforcement in decentralised governance systems: toward a nationwide level playing field. OECD Environment Working Papers, 34. doi:10.1787/5kgblm60qtq6-en.

MBPR. (2015). Stan aktualności studiów uwarunkowań i kierunków zagospodarowania przestrzennego gmin w województwie mazowieckim. Retrieved 18.03.2020 from https://www.mbpr.pl.

NIK. (2016). System gospodarowania przestrzenia gminy jako dobrem publicznym. Retrieved 18.03.2020 from https://www.nik.gov.pl.

OECD. (2002). Sustainable development strategies: a resource book. London: Earthscan. 
Proebstl, U. (2003). Natura 2000: the influence of the European directives on the development of nature-based sport and outdoor recreation in mountain areas. Journal for Nature Conservation, 11(4). doi:10.1078/1617-1381-00066.

Prus, B. (2012). Sytuacja planistyczna w Polsce: studium porównawcze. Infrastruktura i Ekologia Terenów Wiejskich, 2(2).

Simeonova, V., Bouwma, I., van der Grift, E., Sunyer, C., Manteiga L., Külvik, M., Suškevičs, M., Dimitrov, S., \& Dimitrova, A. (2017). Natura 2000 and spatial planning: final report for the European Commission. Retrieved 18.03.2020 from https://ec.europa.eu.

Ustawa z dnia 16 kwietnia 2004 r. o ochronie przyrody [Nature conservation act of 16 April 2004] (Dz.U. $2004 \mathrm{nr} 92$ poz. 880) (Poland).

Ustawa z dnia 16 października 1991 r. o ochronie przyrody [Nature conservation act of 16 October 1991] (Dz.U. $1991 \mathrm{nr} 114$ poz. 492) (Poland).

Ustawa z dnia 27 marca 2003 r. o planowaniu i zagospodarowaniu przestrzennym [Act of 27 March 2003 on spatial planning and development] (Dz.U. $2003 \mathrm{nr} 80$ poz. 717) (Poland).

Ustawa z dnia 3 października 2008 r. o udostępnianiu informacji o środowisku i jego ochronie, udziale społeczeństwa w ochronie środowiska oraz o ocenach oddziaływania na środowisko [Act of 3 October 2008 on providing information on the environment and its protection, public participation in environmental protection and on environmental impact assessments] (Dz.U. 2008 nr 199 poz. 1227) (Poland).

Ustawa z dnia 7 lipca $1994 \mathrm{r}$. o zagospodarowaniu przestrzennym [Act of 7 July 1994 on spatial development] (Dz.U. $1994 \mathrm{nr} 89$ poz. 415) (Poland).

Ustawa z dnia 8 marca 1990 r. o samorządzie gminnym [Act of 8 March 1990 on communal self-government] (Dz.U. $1990 \mathrm{nr} 16$ poz. 95) (Poland).

Ustawa z dnia 9 października 2015 r. o zmianie ustawy o udostępnianiu informacji o środowisku i jego ochronie, udziale społeczeństwa w ochronie środowiska oraz o ocenach oddziaływania na środowisko oraz niektórych innych ustaw [Act of 9 October 2015 amending the act on providing information on the environment and its protection, public participation in environmental protection and on environmental impact assessments and certain other acts] (Dz.U. 2015 poz. 1936) (Poland).

Witkowski, J. (2008). Zaangażowanie samorządów gminnych w działania na rzecz ochrony przyrody na przykładzie gmin województwa lubelskiego. Ekonomia i Środowisko, 1(33).

Woźniak, M. (2011). Zrównoważony rozwój jako strategia definiująca nowoczesne gospodarowanie przestrzenią w Polsce (aspekty prawne). Ekonomia i Prawo. Economics and Law, 7(1). doi:10.12775/eip.2011.008.

Woźniak, M. (2015). Gmina wobec obszarów Natura 2000. Przegląd Prawa Ochrony Środowiska, 4. doi:10.12775/PPoS.2015.038. 


\section{Acknowledgements}

Author contributions: author has given an approval to the final version of the article.

Funding: this research was funded by the Lublin University of Technology, Faculty of Management statutory sources. 


\section{Appendix}

Table 1.

The share of areas covered by legal forms of nature protection in the total area of examined communes (as of December 28, 2019)

\begin{tabular}{lcc}
\hline & Percentage of total area & Number of communes \\
\hline $0-20$ & 24 \\
$20-40$ & 12 \\
$40-60$ & 8 \\
$60-80$ & 3 \\
$80-100$ & 2 \\
\hline
\end{tabular}

Source: Own preparation based on GUS (2019).

Table 2.

The share of areas covered by local spatial development plans in the total area of examined communes (as of December 28, 2019)

\begin{tabular}{|c|c|}
\hline Percentage of total area & Number of communes \\
\hline $0-1$ & 10 \\
\hline $1-10$ & 5 \\
\hline $10-20$ & 2 \\
\hline $20-40$ & 3 \\
\hline $70-80$ & 1 \\
\hline 90-99 & 2 \\
\hline $99-100$ & 26 \\
\hline
\end{tabular}

Source: Own preparation based on GUS (2019).

Table 3.

The number of communes by the time of passing the study of conditions and directions of spatial development (as of April 30, 2019)

\begin{tabular}{lc}
\hline \multicolumn{1}{c}{ Time of passing } & Number of communes \\
\hline less than 5 years ago & 22 \\
$5-10$ years ago & 9 \\
$10-15$ years ago & 3 \\
more than 15 years ago & 15 \\
\hline
\end{tabular}

Source: Own preparation. 
Table 4 .

The number of communes by the nature inventory time (as of April 30, 2019)

\begin{tabular}{lc}
\hline \multicolumn{1}{c}{ Inventory time } & Number of communes \\
\hline less than 5 years ago & 9 \\
5-10 years ago & 7 \\
more than 10 years ago & 20 \\
never & 13 \\
\hline
\end{tabular}

Source: Own preparation. 